\title{
Synonymic Syntagms and Utterances as Phenomenologically Reconstructed Discourse Innovations (on the material of modern French fiction)
}

\section{Синонімічні синтагми та висловлення як феноменологічно реконструйовані мовленнєві інновації (на матеріалі сучасної французької художньої прози)}

\author{
Anastasiia Lepetiukha \\ Ph.D. in Philology, \\ Assistant Professor
}

\author{
Анастасія Лепетюха \\ кандидат філологічних наук, \\ доцент
}

\section{E-mail: lepetyukha.anastasiya@gmail.com orcid.org/0000-0002-2812-4510}

\section{H.S. Skovoroda Kharkiv National Pedagogical University, Department of Romance Philology $\triangle 2$, Valentynivska Str., Kharkiv, Ukraine, 61070}

\author{
Харківський національний \\ педагогічний університет \\ імені Г.С. Сковороди, \\ кафедра романської філології \\ $\bowtie$ вул. Валентинівська, 2, \\ м. Харків, Україна, 61070
}

Original manuscript received February 28, 2018
Revised manuscript accepted January 11, 2019

\section{ABSTRACT}

The phenomenon of syntactic synonymy in mono- and polypredicative utterances of modern French fiction prose is considered in this article from the standpoint of phenomenology. The phenomenological method of cognition of being and its structures and categories, which is based on the human tendency to study objects of observation in the form they appear in consciousness, is aimed at ontology. It is proved that in 
the process of learning about being relations mind $\rightarrow$ language correspond to the first phase of polyoperations of reconstruction of phenomenological organization of the universe; the continuum language $\rightarrow$ discourse corresponds to the second phase. Three stages of phenomenological construction of synonymic structures at the levels of primary and secondary consciousness are distinguished: 1) destruction and reconstruction of being as the result of observing its structures and categories (primary consciousness (inconscious mental operations)) $\rightarrow$ sublinguistic schemes (subconscious stratum of secondary consciousness); 2) sublinguistic schemes $\rightarrow$ primary syntagms and propositions (surface stratum of secondary consciousness); 3) primary syntagms and propositions $\rightarrow$ secondary reduced, extended and quantitatively equally componental transforms (surface stratum of secondary consciousness) actualized in the form of grammatised and typical or atypical agrammatised functionally transposed and notransposed mono- and polypredicative discourse innovations. The typologies of: a) functionally transposed co(n)textually pertinent structures with linear transposition: with the change of volume, equal quantity of lexical elements or with conversion of components of synonymic structures; and b) notransposed compressed, extended and quantitatively equally componental synonymic co(n)textually adequate transforms of primary syntagms and propositions are established. In the course of analysis of utterances with syntactical synonymy a large number of the structures with polysynonymisation at the level of one syntagm or proposition is revealed.

Key words: discourse innovation, monopredicative utterance, phenomenological reconstruction, polypredicative utterance, syntactical synonymy.

\section{Вступ}

«Епістемологічний цоколь» (термін М. Валетта) вивчення синтаксичної синонімії становить конструктивізм, оскільки «генетична, або конструктивістська епістемологія» грунтується на цілях дослідження, на проектах пізнання більш, ніж на предметах. Пізнання осягається тільки через відношення спостерігача i предмета спостереження, воно являє собою процес перш, ніж бути результатом. Таким чином, ідеться про епістемологію акта пізнання, французьку епістемологію (Valette, 2006: 168). Філософським підгрунтям наукового пізнання, зокрема, мови, $\epsilon$ феноменологія як метод, спрямований на онтологію, на суще (Хайдеггер, 2001: 23).П.Літвін зазначає, що «феноменологія повинна розумітися як дескриптивний метод, метою якого $є$ розкриття структурних інваріантів феномену, що вивчається. Мову як феномен, що піддається структурному аналізу, доцільно вивчати 
3 позицій феноменології» (Litwin, 2016: 188). У феноменології протиставляються «універсум у мені» й «універсум поза мене», який сприймається органами почуттів. При цьому автор повідомлення $є$ одночасно «автором того, що спостерігається» (Guillaume, 1969: 27).

У менталістській концепції Г. Гійома велика увага приділяється відношенням семасіологічного і психічного позначуваних, що, на думку вченого, представляють справжню лінгвістичну реальність (Гийом, 2004: 54). Р. Якобсон зазначає, що «свідоме і несвідоме є у рівній мірі співупорядкованими всередині «єдиної системи їхніх відношень» (Якобсон, 1996: 24). Д. Сьорл вважає, що «коли ми описуємо щось як несвідомий ментальний стан, ми характеризуємо об'єктивну онтологію на підставі іiі каузальної здатності породжувати свідомість» (Сёрл, 2002: 154-155).

У феноменологічному описі мови, іiі буття привілейована роль належить свідомості, оскільки «приоритет свідомості розповсюджується на саме існування людини ...» (Макаров, 2003: 28). Згідно з Е. Гуссерлем, в основі методу феноменології лежить прагнення людини вивчати об'єкти поза їхнім реальним, матеріальним існуванням і змістовим боком у тому вигляді, в якому вони безпосередньо постають перед свідомістю - як об'єкти інтенціонального споглядання і переживання (Эстетика, 1989: 370).

На думку М.Л. Макарова, «феноменологія включає несвідоме до загального об'єму предмета аналізу як особливу модальність свідомості» (Макаров, 2003: 29). При цьому «феномен свідомості корелює лише 3 його представленням, а не 3 реальним буттям» (там само: 30), оскільки «без попередньої репрезентації у свідомості $€$ неможливим наступне вираження у мові» (Adam, 2008: 27).

Характеризуючи феноменологію як метод пізнання буття та його структур і категорій, спрямований на онтологію, М. Хайдеггер указує, що саме буття дається лише тоді, коли існує розуміння буття. Буття a priori з'являється раніше за суще (Хайдеггер, 2001: 23-24). Виділення буття сущого та експлікація самого буття становлять завдання онтології (там само: 27). Суще претендує на виключну позицію у феноменологічній проблематиці (там само: 23). Взагалі, всі положення онтології мають характер «veritas temporalis» (там само: 430): мова становить фундамент лінгвістичної онтології, вона постійно перебуває у голові людини як можливість (поза актом висловлювання). Між мовою і мовленням існує непомітний 
онтологічний перехід, оскільки мовлення $є$ «процесом свідомості, вираженим за допомогою знаків; мова об'єктивно присутня у мовленні» (Савченко, 1986: 70).

Відсутність у вітчизняному та зарубіжному мовознавстві комплексного аналізу моно- та поліпредикативних висловлень iз синтаксичною моно- та полісинонімією як феноменологічно реконструйованих мовленнєвих інновацій у континуумі мовамовлення обумовлює актуальність та цінність цієї наукової розвідки для розвитку сучасної лінгвістики та психолінгвістики.

Метою статmі $є$ дослідження процесів поетапного феноменологічного конструювання віртуальних (мовних) первинних синтагм i пропозицій та вторинних синонімічних структур, а також побудова типології ко(н)текстуально пертинентних монота поліпредикативних мовленнєвих інновацій із синтаксичною синонімією (далі - СС).

\section{Методи та методики дослідження}

У статті використовуються дедуктивно-гіпотетичний метод, що передбачає розкриття психологічних фактів формування у свідомості складних знаків, та феноменологічний метод як підгрунтя епістемології, спрямований на онтологію, що дозволяє виявити процеси конструювання віртуальних синонімічних трансформів.

\section{Результати та дискусії}

У процесі пізнання буття та його структур і категорій першому етапу поліоперацій реконструювання феноменологічної організації всесвіту відповідають відношення мислення $\rightarrow$ мова; другому етапу - континуум мова / мовлення.

На рис. 1. представлено поетапну інтеграцію підсистем: мислення, мова, мовлення у діалектичну систему.

Таким чином, підсистемні когнітивні поліоперації (діяльність психомеханізмів) феноменологічного реконструювання дискурсивних одиниць, зокрема синонімічних структур, починаються при переході мислення до мови на вісі оперативного часу кінетизму (руху) думки і закінчуються актуалізацією простих і складних мовних знаків. 
Synonymic Syntagms and Utterances as Phenomenologically...

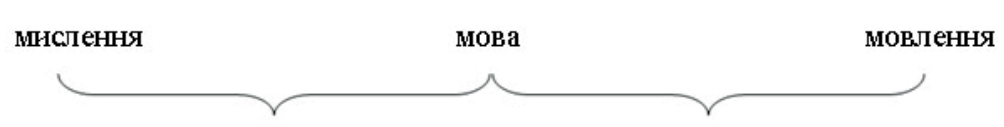

I етап підсистемннх поліоперацій II етап підсистемннх поліоперацій

\section{діалектична система}

Рис. 1. Феноменологічне реконструювання буття

3 понятійною інтерпретацією буття, що виявляється в редукції та реконструкції його структур, пов’язана певна деструкція, за допомогою якої «онтологія може забезпечити (...) справжність своїх понять» (Хайдеггер, 2001: 27). Отже, деструкція, редукція та реконструкція є змістовно взаємопов'язаними. В онтологічному дослідженні вони можуть використовуватися за необхідності i залежно від завдань конкретного опису, але «... шляхом феноменологічного методу буття повинно бути охоплено та осягнено у понятті ...» (там само: 25). При цьому предметне буття $є$ корелятом свідомості в особливому сенсі - «як сприйняте, представлене, прийняте на віру припущення» (Гуссерль, 1911: 14).

Згідно 3 Ш. Баллі «форма повідомлення думки встановлює чітку різницю між представленням, яке сприймається почуттями, пам'яттю або уявленням, і психічною операцією, що проводиться суб'єктом мислення над цією формою» (Балли, 1955: 44). А.Ю. Агафонов виділяе два блоки психічного апарату: когнітивне несвідоме та когнітивне свідоме (Агафонов, 2014: 27). На думку Г. Гійома, «у мові на конструкцію, побудовану у мисленні, накладається конструкція, побудована у знаках» (Guillaume, 1969: 28).

Таким чином, феноменологічні редукція та реконструкція (розширення, побудова кількісно рівнокомпонентних (термін автора) структур) мовних знаків становлять процеси, що призводять до ясності та є пов'язаними 3 загальним поняттям інтенціональності мовця, тобто особливими типами, станами, спрямованостями та рівнями свідомості, які розрізняються у іiі межах.

Отже, видається можливим припустити існування неусвідомленого, підсвідомого та поверхневого шарів свідомості, які ми визначаємо як первинну та дворівневу вторинну свідомості, що схематично представлені на рис. 2. 
Синонімічні синтагми та висловлення як феноменологічно...

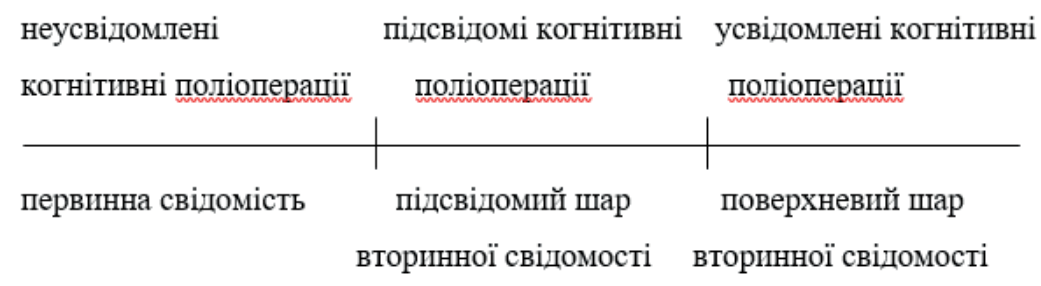

Рис. 2. Первинна та вторинна свідомості

На різних рівнях свідомості відбувається трьохетапне феноменологічне конструювання синонімічних структур: 1) деструкція та реконструювання буття через спостереження його структур і категорій (первинна свідомість) $\rightarrow$ сублінгвістичні схеми, або «когнітивні кореляти ситуації» (Дейк ван, 1989: 69), ментальні сутності, які можуть бути визначені «як мінімальні одиниці ментальної інформації» (Gineste, 2003: 48), що «перебувають у глибині мовної системи» (Boone \& Joly, 1986: 371) у вигляді типових моделей, за зразком яких відтворюються численні структури (підсвідомий шар вторинної свідомості)); 2) сублінгвістичні схеми $\rightarrow$ первинні (стрижневі) синтагми та пропозиції (поверхневий шар вторинної свідомості)); 3) первинні синтагми та пропозиції $\rightarrow$ редуковані, розширені та кількісно рівнокомпонентні синонімічні трансформи (поверхневий шар вторинної свідомості). На рис. 3. схематично представлено процес формування та породження висловлень із СС на різних рівнях свідомості.

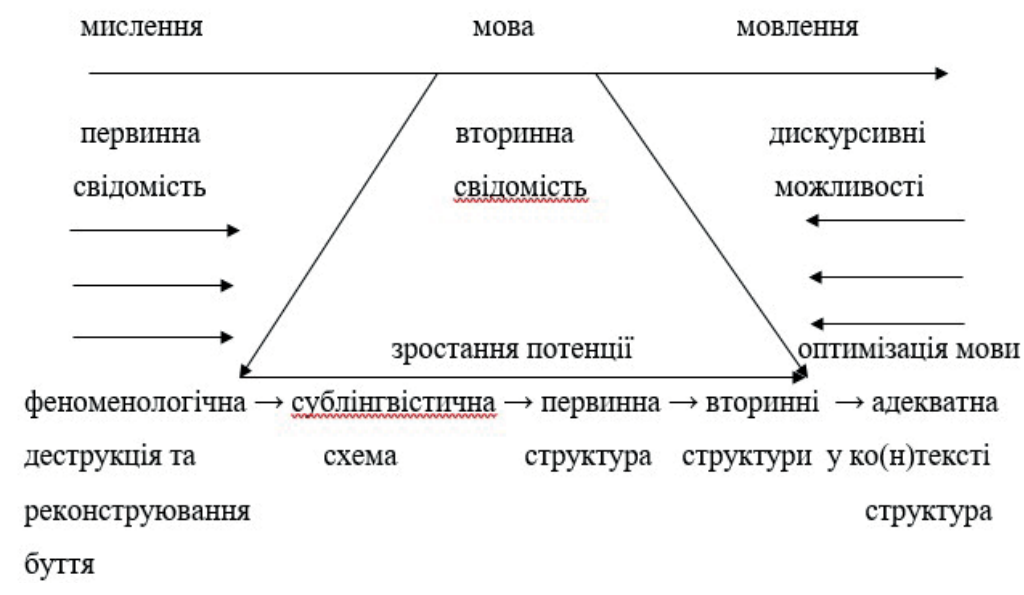

Рис. 3. Каузаиія моно- та поліпредикативних висловлень із СС 
Очевидно, що феноменологічний метод дослідження формування та актуалізації синонімічних конструкцій дозволяє виявити когнітивні операції, що діють на рівні підсистем діалектичної єдності мислення $\rightarrow$ мова $\rightarrow$ мовлення та різних шарів свідомості 3 поступовим зростанням потенції мови (первинна структура $\rightarrow$ синонімічний ряд вторинних одно- та двобазових трансформів (з одним та двома трансформаційними термінальними ланцюжками)), яка оптимізується (реалізує свої можливості з максимальною ефективністю) (Минкин, 2012: 99) у мовленні у вигляді складних знаків - ко(н)текстуально адекватних граматизованих (нормативних у мові та мовленні) або типових (нормативних у мовленні) і нетипових (ненормативних у мові та мовленні) аграматизованих «функціональних домінант» (термін Ш. Баллі) (Балли, 1955: 129) у різних дискурсивних формаціях. Дискурсивні можливості, тобто ко(н)текстуалізація творчих реалізацій суб'єкта мовлення зумовлені знаковою природою лінгвістичних одиниць та відношеннями між позначувальним i позначуваним. В актуалізованих у конкретних ко(н)текстах структурах постійно виникають конфронтації між ментальними i структурними константами, пов'язані 3 креативною мовленнєвою діяльністю людини, у результаті змінюється їхнє співвідношення в алгоритмічно заданих побудовах, тобто «змінюються межі несвідомого і свідомого в операціях побудови висловлення» (Минкин, 2008: 7).

М. Валет підкреслює, що «феноменологічний дискурс - це дискурс про порядок та безпорядок, де безпорядок відноситься до дискурсу, а порядок - до мови» (Valette, 2006: 52). У процесі феноменологічного конструювання синонімічних структур результатом конфронтацій є так званий «дискурсивний безпорядок», що виявляється в актуалізації структурно та семантично нюансованих трансформів - членів віртуального синонімічного ряду 3 асиметрією позначувального і позначуваного, що зумовлено полікомпонентністю синонімічних конструкцій та полівалентністю головних лексем. Очевидно, що «висловлення ніколи не $\epsilon$ ізольованим у тому сенсі, що воно становить частину родини споріднених висловлень; але висловлення є завжди оригінальним, у тому сенсі, що воно завжди модулюється специфічним засобом» (Fuchs, 1994: 146). Спільну думку висловлює А. Кюльолі: 
«будь-яке висловлення є одиничним серед інших (...), воно являє собою частину родини перифрастичних трансформів; але не існує висловлення, яке б не було змодульованим, тобто не було б унікальним феноменом» (Culioli, 1973: 86-87).

У процесі трансформації стрижневої структури може відбуватися «функціональна транспозиція» вторинних синонімічних синтагм та пропозицій, що у певних ко(н)текстах виступають функціональними домінантами. Ш. Баллі зазначає, що «всіляке висловлення є обумовленим логічно, психологічно та лінгвістично. Ці три аспекти лише частково перекривають один одного; роль, яку виконує кожний 3 них, $\epsilon$ вкрай мінливою i по-різному усвідомлюється при втіленні у мовленні. Тільки аналіз дозволяє виявити їх завдяки узгодженості безпосередніх асоціацій (...), притаманних даному стану мови; такі асоціації дозволяють розкрити функціональні еквівалентності, що лежать в основі всілякої мовної системи» (Балли, 1955: 41). Вчений вважає, що функціонально еквівалентними $є$ ті частини граматичної системи, які можуть взаємозамінятися в силу їхньої загальної функції, для чого зовсім не потрібна тотожність їхніх семантичних або стилістичних значень (там само: 49). Систему граматичних замін Ш. Баллі називає функціональною транспозицією (там само: 129).

Аналіз прикладів моно- та поліпредикативних висловлень із СС сучасної французької художньої прози дозволив виділити функціонально транспоновані та нетранспоновані синонімічні трансформи-складні знаки, типологію яких подано на рис. 4.

Серед функціонально транспонованих ко(н)текстуально пертинентних структур виділено синонімічні конструкції з лінійною транспозицією (термін А. Фрея), тобто зміною об’єму, рівною кількістю лексичних елементів або зі зміною напряму задієних елементів (з конверсією (термін А. Фрея)) (Фрей, 2006: 204) iз незмінними насиченістю та значенням (там само: 197); нетранспоновані синонімічні структури поділяємо на компресовані, розширені і кількісно рівнокомпонентні ко(н)текстуально адекватні трансформи первинних синтагм та пропозицій. До функціонально транспонованих одно- та двобазових синонімічних перифраз зі зміною об'єму відносимо: а) звужені та розширені монопредикативні висловлення (далі - МПВ), ускладнені дієприслівниковим або суб'єктним (тим, що відноситься до підмета) дієприкметниковим 


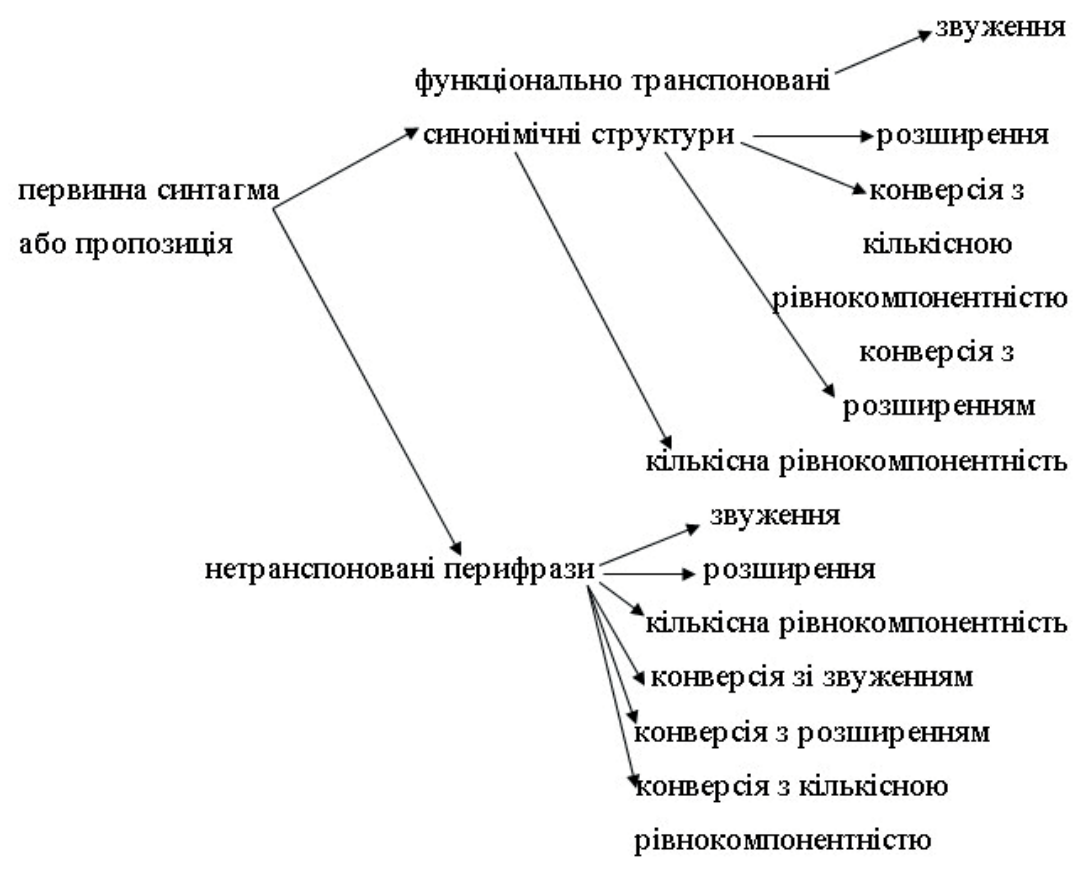

Рис. 4. Типи функціонально транспонованих і нетранспонованих однота двобазових синонімічних трансформів

зворотами; б) моно- та поліпредикативні конструкції 3 CC 3 інфінітивом / інфінітивним зворотом-підметом та присудком; в) контаміновані МПВ та поліпредикативні висловлення (далі ППВ); г) складні інфінітивні конструкції 3 адвербіальною лексемою, що заміщує предикативну стрижневу структуру; д) МПВ, розширені десемантизованими предикатами aller, être та avoir, адвербіально-вербальними аналітичними конструкціями: être + en train de, en cours de, en passe de, sur le point de тощо, специфічним суб'єктним інфінітивним зворотом: être + $\mathrm{D}(\grave{a})+$ Inf; (де Inf - інфінітив; D - стимулятор ідентифікації референтів (déclencheur) (Charolles, 2002: 127)); е) звужені МПВ 3 ініціальною синонімічною номінальною синтагмою зі стимуляторами dès, avant, après тощо; $\epsilon$ ) компресовані МПВ зі стимуляторами de retour, de passage тощо; ж) розширені контаміновані ППВ, типу: c'est + Inf; 3) умовні, концесивні та темпоральні синонімічні підрядні частини ППВ; i) специфічні синонімічні інфінітивні підрядні висловлення 3 номінальними (le temps, histoire, manière) та адвербіальним 
(autant) компонентами; ї) підрядні висловлення 3 абсолютними дієприкметниковим або дієприслівниковим зворотами та з об'єктним (тим, що відноситься до додатку) дієприкметниковим зворотом; к) звужені сполучникові ППВ із конектором que.

Серед функціонально транспонованих неконверсивних кількісно рівнокомпонентних синтагм та висловлень із СС виділяємо: a) специфічні інфінітивні звороти, побудовані за синтаксичними моделями: être + іменна частина присудку + D $(\grave{a})+\mathrm{Inf}$ та avoir + $\mathrm{COD}+\mathrm{D}(\grave{a})+\operatorname{Inf}($ де COD - прямий додаток); б) контаміновані кількісно рівнокомпонентні інфінітивні звороти: c'est + $\mathrm{CP}+$ $\mathrm{D}(\grave{a})+\operatorname{Inf}$ (де CP - предикативний додаток). Функціонально транспоновані конструкції зі зміною напряму складників синтагм та висловлень поділяємо на конверсивні (пасивізація з неактивним суб'єктом дії) та конверсивно-розширені (пасивізація 3 активним суб'єктом дії) структури.

Нетранспоновані одно- та двобазові синонімічні трансформи поділяємо на конструкції: 1) зі звуженням первинної структури: а) вербальні МПВ 3 ініціальним, медіальним та фінальним еліпсисом; б) інверсивні МПВ 3 предикативною конструкцією типу Рp або аграматизованим Р у кондиціоналі + je (де $\mathrm{Pp}-$ дієприкметник теперішнього часу; $\mathrm{P}$ - предикат / предикативна синтагма) 3 ініціальним питальним зворотом est-ce que; в) інверсивні конструкції типу $\mathrm{P}$ у кондиціоналі $+\mathrm{S}$ (де $\mathrm{S}-$ субстантив / номінальна синтагма / прономінальний / нумеральний компоненти) та МПВ 3 ініціальною ад'єктивною лексемою + $\mathrm{COI}+\mathrm{Inf}$ (де COI - непрямий додаток); г) МПВ 3 апозитивними субстантивом або номінальною синтагмою; д) еліптичні номінальні висловлення або синтагми; е) МПВ із ініціальною синонімічною номінальною синтагмою зі стимуляторами часу une fois, à peine; є) МПВ із синонімічною номінальною синтагмою, побудованою за моделлю: sans + C + S + Р (де C - додаток); ж) МПВ із синонімічною номінальною синтагмою зі сполучниками підрядності bien que / quoique (рідше parce que); 3) номінально-вербальні МПВ; i) прономінальні та нумеральні еліптичні МПВ; ї) еліптичні ад'єктивно-вербальні МПВ; й) еліптичні адвербіально-вербальні конструкції; к) монопредикативні побудови зі стимулятором une fois; л) заперечно-інверсивні синонімічні умовні підрядні висловлення безсполучникових та сполучникових ППВ; 
м) еліптичні МПВ із дієприкметниковою або дієприслівниковою головними лексемами; н) синонімічні підрядні висловлення 3 головними номінальною, ад'єктивною та адвербіальною лексемами та 3 пре- й інтерпозитивними стимуляторами часу une fois та à peine; 2) 3 розширенням первинної структури: а) МПВ, розширені прислівниками peut-être та seulement; б) синонімічні структури, розширені анафоричними, катафоричними особовими займенниками, вказівними займенниками, прономінальним компонентом quе, «деміактивним» (Копров, 2010: 153) невизначеним прономінальним актантом il (імперсональні конструкції); в) МПВ, розширені номінальним або нумеральним компонентами; г) ППВ iз презентативами-розширювачами (c'est ... que / qui, voilà ... que / qui тощо); д) нетипові аграматизовані синонімічні ППВ 3 інверсивним екзистенційним зворотом est-ce; 3) 3 кількісною рівнокомпонентністю: інверсивні МПВ типу: (D) $\mathrm{P}+\mathrm{S}$. Конверсія зі звуженням та прономінальним розширенням спостерігається у нетранспонованих еліптичних двокомпонентних ад'єктивно та адвербіально-вербальних МПВ; конверсія 3 прономінальним розширенням - у синонімічних ППВ з quе; конверсія з розширенням презентативом ce qui ... (c') est - у ППВ із CC; конверсія та кількісна рівнокомпонентність зустрічається у синонімічних підрядних частинах ППВ зі сполучниками que та $s i$.

У процесі трансформації первинних структур може відбуватися подвійна, потрійна тощо синонімізація на рівні однієї синтагми або пропозиції, тобто формування функціонально транспонованих та / або нетранспонованих конструкцій, що актуалізуються у вигляді полісинонімічних синтагм та моно- і поліпредикативних висловлень.

\section{Висновки}

Проведене дослідження дозволило виявити функціонально транспоновані та нетранспоновані різноструктурні (компресовані, розширені, кількісно рівнокомпонентні) граматизовані та типові i нетипові аграматизовані моно- та поліпредикативні моно- i полісинонімічні мовленнєві інновації 3 різними головними лексемами, що формуються у мові у результаті феноменологічного реконструювання буття та його структур i категорій на різних рівнях вторинної свідомості: сублінгвістичні схеми (підсвідомий 
шар вторинної свідомості) $\rightarrow$ стрижневі синтагми та пропозиції (поверхневий шар вторинної свідомості) $\rightarrow$ синонімічний ряд однота двобазових трансформів (поверхневий шар вторинної свідомості). Перспективним $є$ дослідження процедур зворотної реконструкції феноменологічно побудованих членів віртуальних синонімічних рядів на основі спостереження мовленнєвих інновацій адресатом повідомлення.

\section{Література}

Агафонов А.Ю. Эволюционная эпистемология и когнитивная психология сознания, или зачем человеку разум? Психолінгвістика. Психолингвистика. Psycholinguistics. 2014. Вип. 17. С. 18-40.

Балли Ш. Общая лингвистика и вопросы французского языка. Москва : Изд-во иностранной литературы, 1955. 416 с.

Гийом Г. Принципы теоретической лингвистики. Москва : Едиториал УРСС, 2004. 224 c.

Гуссерль Э. Философия как строгая наука. Логос. 1911. Кн. 1. С. 1-56.

Дейк ван Т. Язык. Познание. Коммуникация. Москва : Прогресс, 1989. 312 с.

Копров В.Ю. Семантико-функциональный синтаксис русского языка в сопоставлении с английским и венгерским. Воронеж : Издатель О.Ю. Алейников, 2010. 328 с.

Макаров М.Л. Основы теории дискурса. Москва : Гнозис, 2003. 280 с.

Минкин Л.М. Предложение, высказывание, речевой акт. Вісник Київського національного лінгвістичного університету. Серія Філологія. 2008. Т. 10. № 2. C. 5-15.

Минкин Л.М. Теория лингвистического ментализма Г. Гийома и вопросы нейролингвистики. Вісник Киїського національного лінгвістичного університету. Серія Філологія. 2012. Т. 1. № 2. С. 98-110.

Савченко А.Н. Лингвистика речи. Аспекты общей и частной лингвистки теории текста. 1986. № 3. С. 62-74.

Сёрл Д. Открывая сознание заново. Москва : Идея-Пресс, 2002. 256 с.

Фрей А. Грамматика ошибок. Москва : КомКнига, 2006. 304 с.

Хайдеггер М. Основные проблемы феноменологии. Санкт-Петербург : Высшая религиозно-философская школа, 2001. 446 с.

Эстетика : Словарь / Под. общ. ред. А.А. Беляева и др. Москва : Политиздат, 1989. 447 c.

Якобсон Р. Язык и бессознательное. Москва : Гнозис, 1996. 248 с.

Adam, J.-M. (2008). Les textes: types et prototypes. Paris : Armand Colin.

Boone, A., \& Joly, A. (1986). Dictionnaire terminologique de la systématique du langage. Paris : Harmattan.

Charolles, M. (2002). La référence et les expressions référentielles en français. Paris : Éditions Ophrys.

Culioli, A. (1973). Sur quelques contradictions en linguistique. Communications, 20(1), 83-91. https://doi.org/10.3406/comm.1973.1298 
Synonymic Syntagms and Utterances as Phenomenologically...

Fuchs, C. (1994). Paraphrase et énonciation. Paris : Ophrys.

Gineste, M.-D. (2003). De la phrase à la proposition sémantique : un point de vue de la psychologie cognitive du langage. L'information grammaticale, 98, 48-51. https://doi.org/10.3406/igram.2003.2615

Guillaume, G. (1969). Langage et science du langage. Paris : Librairie A.-G. Nizet; Québec : Les presses de l'Université Laval.

Litwin, P. (2016). Book review : Beata Stawarska, Saussure's Philosophy of Language as Phenomenology : Undoing the Doctrine of the Course in General Linguistics. Oxford : Oxford University Press 2015, 286 pp. Psychology of Language and Communication, 20(2), 182-190. https://doi.org/10.1515/plc-2016-0010

Valette, M. (2006). Linguistiques énonciatives et cognitives françaises. Gustave Guillaume, Bernard Pottier, Maurice Toussaint, Antoine Culioli. Paris : Édition Honoré Champion.

\section{References}

Agafonov, A. (2014). Evolyucionnaya epistemologiya i kognitivnaya psikhologiya soznaniya, ili zachem cheloveku razum? [Evolutionary Epistemology and Cognitive Psychology of Consciousness, or Why Does a Man Need a Mind?]. Psikholingvistika - Psycholinguistics, 17, 18-40 [in Russian].

Balli, Sh. (1955). Obshchaya lingvistika $i$ voprosy francuzskogo yazyka [General linguistics and French questions]. Moscow : Izd-vo inostrannoy literaturyi [in Russian].

Belyaev, A. (1989). Estetika : Slovar [Aesthetics : Dictionary]. Moscow : Politizdat [in Russian].

Deyk van, T. (1989). Yazyik. Poznanie. Kommunikatsiya [Language. Knowledge. Communication]. Moscow : Progress [in Russian].

Frey, A. (2006). Grammatika oshibok [Grammar of errors]. Moscow : KomKniga [in Russian].

Giyom, G. (2004). Principy teoreticheskoj lingvistiki [Principles of theoretical linguistics]. Moscow : Editorial URSS [in Russian].

Gusserl, E. (1911). Filosofiya kak strogaya nauka [Philosophy as a rigorous science]. Logos - Logos, 1, 1-56 [in Russian].

Haydegger, M. (2001). Osnovnye problemy fenomenologii [The main problems of phenomenology]. St. Petersburg : Vyisshaya religiozno-filosofskaya shkola [in Russian].

Koprov, V. (2010). Semantiko-funkcionalnyj sintaksis russkogo yazyka v sopostavlenii $s$ anglijskim $i$ vengerskim [Semantic-functional syntax of Russian in comparison with English and Hungarian]. Voronezh : Izdatel O.Yu. Aleynikov [in Russian].

Makarov, M. (2003). Osnovy teorii diskursa [Fundamentals of the theory of discourse]. Moscow : Gnozis [in Russian].

Minkin, L. (2008). Predlozhenie, vyiskazyivanie, rechevoy akt [Proposition, utterance, speech act]. Visnyk Kiyivskogo nationalnogo lingvistichnogo universitetu. Seriya Filologiya - Messenger of the Kiev National Linguistic University. Philology Series, 10(2), 5-15 [in Russian].

Minkin, L. (2012). Teoriya lingvisticheskogo mentalizma G. Giyoma i voprosyi neyrolingvistiki [The theory of linguistic mentalism of G. Guillaume and 
issues of neurolinguistics]. Visnyk Kiyivskogo natsionalnogo lingvistichnogo universitetu. Seriya Filologiya - Messenger of the Kiev National Linguistic University. Philology Series, 1(2), 98-110 [in Russian].

Savchenko, A. (1986). Lingvistika rechi [Linguistics of speech]. Aspektyi obschey $i$ chastnoy lingvistiki teorii teksta - Aspects of the general and particular linguistics of the theory of the text, 3, 62-74 [in Russian].

Searle, D. (2002). Otkryvaya soznanie zanovo [Revealing consciousness again]. Moscow : Ideya-Press [in Russian].

Yakobson, R. (1996). Yazyk $i$ bessoznatelnoe [The language and the unconscious]. Moscow : Gnozis [in Russian].

Adam, J.-M. (2008). Les textes: types et prototypes. Paris : Armand Colin.

Boone, A., \& Joly, A. (1986). Dictionnaire terminologique de la systématique du langage. Paris : Harmattan.

Charolles, M. (2002). La référence et les expressions référentielles en français. Paris : Éditions Ophrys.

Culioli, A. (1973). Sur quelques contradictions en linguistique. Communications, 20(1), 83-91. https://doi.org/10.3406/comm.1973.1298

Fuchs, C. (1994). Paraphrase et énonciation. Paris : Ophrys [in French].

Gineste, M.-D. (2003). De la phrase à la proposition sémantique : un point de vue de la psychologie cognitive du langage. L'information grammaticale, 98, 48-51. https://doi.org/10.3406/igram.2003.2615

Guillaume, G. (1969). Langage et science du langage. Paris : Librairie A.-G. Nizet; Québec : Les presses de l'Université Laval.

Litwin, P. (2016). Book review : Beata Stawarska, Saussure's Philosophy of Language as Phenomenology : Undoing the Doctrine of the Course in General Linguistics. Oxford : Oxford University Press 2015, 286 pp. Psychology of Language and Communication, 20(2), 182-190. https://doi.org/10.1515/plc-2016-0010

Valette, M. (2006). Linguistiques énonciatives et cognitives françaises. Gustave Guillaume, Bernard Pottier, Maurice Toussaint, Antoine Culioli. Paris : Édition Honoré Champion [in French].

\begin{abstract}
АНОТАЦІЯ
Явище синтаксичної синонімії у моно- та поліпредикативних висловленнях сучасної французької художньої прози розглянуто у чій статті з позицій феноменології як методу пізнання буття та його структур $і$ категорій, спрямованого на онтологію, в основі якого лежить прагнення людини вивчати об'єкти спостереження у тому вигляді, в якому вони постають перед свідомістю. Виявлено, що у процесі пізнання буття першій фразі поліоперацій реконструювання феноменологічної організації всесвіту відповідають відношення мислення $\rightarrow$ мова; другій - континуум мова / мовлення. Виділено три етапи феноменологічного конструювання синонімічних структур на рівнях первинної та вторинної свідомості: 1) деструкція та реконструювання буття у результаті спостереження його структур і категорій (первинна свідомість (неусвідомлені розумові операчії)) $\rightarrow$ сублінгвістичні схеми (підсвідомий шар вторинної свідомості); 2) сублінгвістичні схеми $\rightarrow$ первинні
\end{abstract}


Synonymic Syntagms and Utterances as Phenomenologically...

синтагми та пропозиції (поверхневий шар вторинної свідомості); 3) первинні синтагми та пропозиції $\rightarrow$ вторинні редуковані, розширені та кількісно рівнокомпонентні трансформи (поверхневий шар вторинної свідомості), що актуалізуються у вигляді граматизованих та типових або нетипових аграматизованих функціонально транспонованих $і$ нетранспонованих моно- та поліпредикативних мовленнєвих інновацій. у статmі побудовано типології: а) функціонально транспонованих ко(н)текстуально пертинентних синонімічних синтагм та висловлень з лінійною транспозицією: зі зміною об'єму, рівною кількістю лексичних елементів або з конверсією складників синонімічних структур; б) нетранспонованих компресованих, розширених i кількісно рівнокомпонентних ко(н)текстуально адекватних трансформів первинних синтагм та пропозицій. В ході аналізу висловлень із синтаксичною синонімією виявлено велику кількість структур із полісинонімізацію на рівні однієї синтагми або пропозиції.

Ключові слова: мовленнєва інновація, монопредикативне висловлення, поліпредикативне висловлення, синтаксична синонімія, френоменологічне реконструювання.

Лепетюха Анастасия. Синонимические синтагмы и высказывания как феноменологически реконструированные речевые инновации (на материале современной французской художественной прозы)

\section{АННОТАЦИЯ}

Явление синтаксической синонимии в моно- и полипредикативных высказываниях современной французской художественной прозы рассматривается в этой статье с позиций феноменологии как метода познания бытия и его структур и категорий, направленного на онтологию, в основе которого лежит стремление человека изучать объекты наблюдения в том виде, в каком они предстают перед сознанием. Выявлено, что в процессе познания бытия первой фазе полиопераций реконструирования феноменологчческой организации вселенной соответствуют отношения мышление $\rightarrow$ язык; второй - континуум язык / речь. Выделено три этапа феноменологического конструирования синонимических структур на уровнях первичного и вторичного сознания: 1) деструкция и реконструирование бытия в результате наблюдения его структур и категорий (первичное сознание (неосознанные мыслительные операции)) $\rightarrow$ сублингвистические схемы (подсознательный слой вторичного сознания); 2) сублингвистические схемы $\rightarrow$ первичные синтагмы и пропозиции (поверхностный слой вторичного сознания); 3) первичные синтагмы и пропозиции $\rightarrow$ вторичные редуцированные, расширенные и количественно равнокомпонентные трансрормы (поверхностный слой вторичного сознания), актуализирующиеся в виде грамматизированных и типичных или нетипичных аграмматизированных функционально транспонированных и нетранспонированных моно- и полипредикативных речевых инноваций. 
Синонімічні синтагми та висловлення як феноменологічно...

В статье построены типологии: a) функционально транспонированных ко(н)текстуально пертинентных структур $c$ линейной транспозицией: с изменением объёма, равным количеством лексических элементов или с конверсией компонентов синонимических структур; б) нетранспонированных компрессированных, расширенных и количественно равнокомпонентных ко(н) текстуально адекватных трансформов первичных синтагм и пропозиций. В ходе анализа высказываний с синтаксической синонимией выявлено большое количество структур с полисинонимизацией на уровне одной синтагмы или пропозиции.

Ключевые слова: монопредикативное высказывание, полипредикативное высказывание, речевая инновачия, синтаксическая синонимия, феноменологчческое реконструирование. 